\title{
“MAARAK KITAB BUKHARI” TRADITION IN BANJAR COMMUNITY
}

\author{
Zulfa Jamalie \\ Faculty of Dakwah and Communication \\ Antasari State Islamic Religion Institute of Banjarmasin \\ Email:zuljamalie@gmail.com
}

\section{Abstract}

This study reviews the local wisdom and harmony in the tradition of Maarak Kitab Bukhari (MKB) in Banjar community. This study uses religious anthropological approaches to explore various ideas and comprehension of the research object. The result shows that this tradition is motivated by environmental condition of Banjar which is prone to fire. As part of a tradition of starting reinforcements, MKB is carried out when people have seen some signs or warnings and dealt with specific situations. This tradition is done at night during dry season when fires frequently happened, with the aim of counteracting the danger of fire and asking for salvation. In this tradition, certain procession is conducted to be a sort of intermediary or the cause so that it prevents from the fire. The agenda consists of doing 'hajat' prayers, reading surah Yaasin, parading the holy book around the village, reciting the lines of 'Burdah', reading salawat 'Kamilah', and praying for salvation. The description of religious values and propaganda contained in this tradition is strong evidence of the ability of the previous scholars to acculturate the comprehension and behavior of Banjar society before the arrival of Islam. MKB is one of the traditions that reflect the meeting between Islam and local culture.

Penelitian ini mengkaji tentang kearifan lokal dan harmoni yang terdeskripsi dalam tradisi Maarak Kitab Bukhari (MKB) pada masyarakat Banjar. Penelitian ini menggunakan pendekatan antropologis keagamaan untuk menggali berbagai pemikiran dan pemahaman masyarakat terhadap objek penelitian. Hasil penelitian menunjukkan bahwa tradisi MKB dilatarbelakangi oleh kondisi 
lingkungan masyarakat Banjar yang rawan terjadi kebakaran. Sebagai bagian dari tradisi tolak bala, MKB dilaksanakan ketika masyarakat telah melihat sejumlah tanda atau peringatan dan berhadapan dengan situasi tertentu. Tradisi ini dilakukan pada malam hari, ketika musim kemarau saat sering terjadi kebakaran dengan tujuan menangkal bahaya kebakaran dan memohon keselamatan. Dalam tradisi ini, dilakukan prosesi tertentu yang diyakini bisa menjadi perantara atau penyebab sehingga kebakaran tidak terjadi. Dimulai dengan pelaksanaan shalat sunnat hajat, diteruskan dengan membaca surat Yaasin, mengarak keliling kampung Kitab Shahih Bukhari, melantunkan syairsyair Burdah, membaca salawat Kamilah, dan ditutup dengan pembacaan doa tolak bala serta doa keselamatan. Deskripsi nilai keagamaan dan dakwah yang terkandung dalam MKB merupakan bukti kuat kemampuan para ulama terdahulu dalam mengakulturasi paham dan perilaku masyarakat Banjar sebelum kedatangan Islam. MKB adalah salah satu tradisi yang mencerminkan pertemuan antara Islam dan budaya lokal.

Keywords: tradition; Maarak Kitab Bukhari; culture; local wisdoms

\section{Introduction}

Banjar community is known as religious community in one side and society that strongly hold tradition on the other side. Many old traditions are still maintained nowadays by Banjar Community, one of them is "Maarak Kitab Bukhari” (MKB).

$\mathrm{MKB}$ is one of the traditional events carried out in Banjar community by parading 'Shahih Bukhari' hadis book around the village while reading verses (syair Burdah) and salawat Kamilah with the purpose of chasing away fire ghost or averting, converting, rejecting the incidence of fire. Ideham (2007: 114) explained that in addition to chasing fire ghost away, this tradition is also carried out when certain regions or villages got epidemic of disease, such as smallpox or febrile convulsion and to prevent from all disaster. MKB process is started with salat hajat together in mosque or musholla, followed by the recitation of surah Yasin and prayers. The parade is subsequently held around village while reciting special verses consisting request or pray for the village to be prevented from danger or contagious disease.

In general, MKB tradition carried out by Banjar community is caused by certain situation or condition, usually related with threat, danger, army reinforcement or future disaster, outbreak of disease, prolonged dry season or drought, and many others. Practically, its main purpose is preventing 
danger or the incidence of fire. It is because fire disaster frequently occur in Banjarmasin, especially during dry season. This disaster is worsen because of wooden housing, rapid settlement location, narrow street access, community negligence, and other factors. The data from Banjarmasin city government revealed that the total fire in Banjarmasin for each year reached more than a hundred case, for example ninety two fires recorded until November 2015. From those cases, $90 \%$ of them caused by electrical short circuit and the rest were due to human error such as forgetting to put out candles when blackout occur, stove explosion, careless cigarette butt littering, forgetting to put out cigarette, insect repellent, and many others.

Such incidents then inflict various solutions to prevent or minimize fire. Not only through modern way by preparing water pump machine and Fire Fighter Front (Barisan Pemadam Kebakaran/BPK), but also with traditional means based on tradition growing within society, one of them is by performing MKB.

Community seriousness in overcoming fire, readiness in performing fire extinction, and providing aid for the victim could be seen from numerous BPK in Banjarmasin. For that reason, Indonesian Record Museum (MURI) gave award in 2004 and 2005 as the most BPK number in Indonesia and in Asia. There were 256 BPK unit in 2004 and 447 in 2015, involving 30.000 personnels.

MKB implementation is crucial seen from the perspective of tradition as well as problem solving. It is believed to contain local value and wisdom inherited by previous generation in addressing certain community life problem and maintaining environment. MKB is as tradition initiated by previous ulama, either as dakwah from previous tradition or as substitution of old tradition. It comprises Islamic teaching value intentionally formatted in the form of culture to be internalized in community life. It is in line with what Kuntowijoyo (2001: 196) said that culture is principally an expression of human idea, creation and intention (in certain community) consisting values and messages of religiosity, philosophical knowledge (life wisdom), and local wisdom or knowledge system.

These knowledge systems were constructed by Banjar community alongside with tradition formation with its entire attitude and symbols. Subsequently, such knowledge systems were utilized as solution in facing various life problems alongside with time development and for the sustainability of culture. These knowledge systems were also manifested in form of code of conduct of various inherited tradition. These tradition and knowledge system 
or local wisdom incepted through long dialogue process between knowledge or old belief (pre-Islamic) and Islam. Therefore, in various attitude or tradition carried out by Banjar community, there is an indication of acculturated old beliefs and Islamic belief (Ideham, 2007L 539). That is why, many people comprehend $\mathrm{KMB}$ as a "religious tradition" which contains religion teaching value.

According to the above explanation, it is interesting to review and question; why is MKB taken as an effort to prevent fire? What actual local wisdom is contained in MKB tradition? It is crucial to reveal the answers of these, not only to provide comprehension toward tradition but also to preserve local wisdom values in line with Islamic teaching, and subsequently inherit such values for future generations as useful knowledge legacy for their betterment. Beside, this research is expected to generate deep comprehension toward Islamic development process. In this case, culture is one of the most effective media utilized by previous ulama to deliver Islamic teaching to society.

\section{Research Method}

In order to attain better and deeper comprehension concerning important meaning and values contained in MKB tradition in Banjar community, this research uses religious anthropological approach. According to Maman et al. (2006: 94), religious anthropological is cultural approach by viewing religion as core of culture. Cultural approach could be interpreted as point of view and treatment toward certain symptom that become attention by using culture as its reference. Similarly, Kahmad (2000: 53) also explained that it is actually cultural approach in which religious is viewed as part of culture. Both idea realization deemed as norm as well as value system owned by community member that binds entire community member.

Based on the description, religious anthropological or cultural anthropological approach in this research is utilized in two ways. First, this approach becomes a method to comprehend Banjar community religious practice through this tradition, Banjar community understanding toward religious teaching, religious teaching internalization strategy in daily life, and explore local wisdom values contained in MKB tradition. Second, to grow the tolerance among Banjar Islamic communities toward local differences, as peaceful religion belief could frequently differ in its local aspects. In addition, it is to develop moderate attitude in viewing certain religious tradition, such as $\mathrm{MKB}$. Accordingly, $\mathrm{MKB}$ as well as other similar conditions develop in 
community shall not be addressed critically and unproportionally. Being critical means not accepting it blindly but proportionally by not categorizing, rejecting, priori, or over in addressing it.

This research was conducted in Banjarmasin, especially in Banjar community suburb region. They commonly still strongly hold their tradition by conducting this MKB tradition according to the time and purpose, as one of solution to prevent fire.

This study uses phenomenological or descriptive qualitative approach. It is used to comprehend and describe various behaviors, comprehension, and local wisdom value contained in MKB tradition. In its application, the analysis based on phenomenological approach is conducted by reviewing the research object or examined community point of view. Therefore the background, attitude, and comprehension of community toward something that become their belief could be well understood.

\section{Literature Review}

\section{Local Wisdom}

Local wisdom is generally interpreted as ideas from local community with wise, wisdom, and good value in nature, and is rooted and followed by its community member. According to Gobyah, local wisdom is truth becoming tradition in certain region. It is a combination between holy values of God commandment and various values. Local wisdom is formed as local community cultural as well as geographical condition excellence in broader meaning. It is past cultural product that is subsequently worth using as life guidance. Though having local value, its value deemed so universal (in Sartini, 2004: 112). According to Geriya, conceptually, local wisdom and local excellence is human wisdom relied in philosophical values ethic, means and traditionally institutionalized behavior. It is a value deemed proper and correct so it could last for long period and is even institutionalized (in Sartini, 2004: 112).

Kartawinata (2001: ix) explained that local wisdom is realization of endurance and growing power manifested through way of life, knowledge, and various life strategies. It is carried out by local community to face challenge and problem in its life fulfillment, as well as in maintaining its culture.

Anthropologically, local wisdom is also known as local knowledge or local genius and becomes basic for the creation of cultural identity. Local genius is one of terms initially introduced by Wales. According to Soebadio, 
local genius is local identity, nation cultural identity and personality that cause a nation to be able to absorb and process foreign culture based on their own characteristic and capability (in Ayatrohaedi, 1986: 18-19). Moendardjito (in Ayathohaedi, 1986: 40-41) stated that local culture elements are potential for local genius as its capability had been tested to withstand until nowadays. Its characteristics are: being able to withstand from outside culture, having ability to accommodate outside culture elements, having ability to integrate outside culture element into original culture, having ability to control, and guide cultural development. Cultural identity could simply be interpreted as detail of number of characteristic of certain culture owned by group of people already known for its boundary compared with other community cultural characteristic. Therefore, in cultural identity determination, we could not just view its physical and biological aspects, but also to review community group identity through thinking, feeling, and behaving order.

Such local wisdom in community could be in various means. According to Sirtha (in Sartini, 2004: 112) local wisdom could be in the form of value, norm, ethic, belief, custom, custom law, and specific rules. Subsequently, it is also explained that such local wisdom lives and develops in various community culture so that its function becomes various as well. Amongst them are, local wisdom serve as natural resource conservation and preservation; human resource development, especially related with life cycle ceremony; culture and science development; advice, belief, literature and taboo; and having social, ethic, moral and political meaning.

As concluded by Nuraeni and Alfan (2012: 63), substantially, local wisdom is values available in certain community, believed for its truth and become guidance in local community daily life. Therefore, local wisdom integrated with local intelligence, creativity and knowledge within community, is a crucial factor in determining community civilization.

\section{Maarak Kitab Bukhari Tradition}

According to Kartawinata (2011: viii), tradition which means traditum is anything transmitted, inherited from past to present. It is in the form of patterns or images of behavior, including belief, rules, suggestion, or prohibition to re-implementing behavior patterns that keep changing. Practically, tradition is realized in certain activity carried out simultaneously and repeatedly as behavior pattern affirmation effort lied in norms of future actions. Such tradition 
realization, in form of activities around life cycle, natural environment, or social environment is subsequently interpreted as local wisdom.

MKB itself comes from the word marak and Kitab Bukhari. Marak or 'parade' in Banjar Language means walking together in crowd in group to accompany someone or holding something, such as torch parade. According to Hapip (2008: 7), several terms rooted from parade (arak) word which means holding or presenting, are arakan (line group), baarak (with parade, conducting parade), and marak (holding or accompanying together in crowd).

In Indonesian language dictionary (2008: 84-85), mengarak means escorting (accompanying, bringing around and so on) together in crowd. The root of mengarak is arak, which means walking together or moving hand in hand, whilst arak-arakan means people convoy or marched. Its synonym applied in kingdom context is kirab, walking around kingdom as the place of certain activity or ceremony, for example in marriage ceremony (Pusat Bahasa, 2008: 777).

Kitab Shahih Bukhari (Bukhari Shahih Book) as object of the parade contains compilation of prophet Muhammad saw arranged by Imam Bukhari whose full name is Abu Abdullah Muhammad bin Islamil bin Ibrahim bin al-Mughirah al-Ja'fari (194-256 H). This is the best collection of Hadis book for Moslems and as first place of kutubussittah (six standardized Hadis book).

MKB procession is started by salat Hajat together in mosque or musholla, followed by the recitation of surah Yaasin and prayers. Subsequently, parade is carried out by surrounding village whilst reciting special verses containing request or prayers together for the village to be dissociated from danger (Ideham, 2007: 114).

After the arrival of Islamic religion, developed and embraced by Banjar community, almost entire tradition underwent transformation through acculturation process, either from the form, bendal or utilized instruments, purpose and intention, as well as philosophical values. For example Manyanggar Banua and several other ceremonies are transformed into selametan with recitation of tahlil, tasbih, tahmid, takbir, salawat, prayers, and others as mantra replacement. Baayun anak and aruh ganal are transformed into Baayun Maulid (Prophet Muhammad SAW commemoration). Sesaji for unseen spirit is transformed into pinduduk and served as alms. Carving or handwriting in various symbol form is turned into calligraphy handwriting, and many others. In this matter, including $\mathrm{MKB}$, Banjar community communal tradition for preventing fire is accompanied with procession and tolak bala prayers.

el Harakah Jurnal Budaya Islam Vol.18 No.2 Tahun 2016 
That is why, up to now, MKB tradition is still carried out by Banjar communities, especially those living in resident settlement area with narrow street access, and house building made of wood, making them prone to fire.

\section{Research Result}

In order to get clear description concerning MKB tradition implementation by Banjar community, the following is description of background, purpose and intention, activity time, equipment, and implementation procession.

\section{Background}

MKB tradition was originally carried out by Banjar community that is the descent of upstream region (nowadays known as Banua Lima region or area). Some said that they came from Negara and some said that this MKB tradition was brought by those from Amunati.

MKB tradition was initially carried out by community because of disease epidemic, such as smallpox and febrile convulsion. Febrile convulsion belongs to deadly disease attacking children. Hence, Balian children frequently are given sawan fruit bracelet to avoid febrile convulsion impact. Another choice, children were worn necklace with small cushion pendant wrapped with black cloth containing wafak.

As time goes by, the reasoning behind this tradition were developed and also carried out by community as they face long dry season, in which fire frequently occur. They assume that MKB is an effective tradition to prevent the fire incidence. MKB shall become a warning for the community to actively keep their environment, raise awareness, and be more careful toward anything that could cause fire.

This tradition was maintained when they migrated and settled in Banjarmasin. The location, narrow streets that trouble BPK vehicle to reach hotspot, old wooden house, inappropriate installation or overlapped old wire, and other causes (human error) making fire likely to occur. In such condition, $\mathrm{MKB}$ is deemed as maximum effort to prevent the village from fire danger. Fire extinguisher tool are available, and communities also keep their awareness. MKB is similar to clock, reminding society that fire could occur anytime and anyplace, so that the best attitude in facing such condition would be raising carefulness and surrender to God. 


\section{Purpose}

$\mathrm{MKB}$ is intended to alter fire incidence as it is the most frequent disaster. Therefore, $\mathrm{MKB}$ is more identical with tolak bala and "fire ghost" chasing away deemed as having noticed for its existence. The community assumes, the sign that could be identified from "fire ghost" existence is whenever they spot fire ghost around their village, usually in the form of fireball flying in the air; fire incidence in nearby village or other place; incoming dry season and others.

It is clear that MKB purpose is asking help from Allah swt. for the village to be dissociated from fire danger and for the salvation of community member . It is done by conducting series of important stages exist in MKB, especially salat Hajat, surah Yaasin recitation, tolak bala prayer, and salvation prayers recitation.

\section{Time}

$\mathrm{MKB}$ is always held at night after salat Isya. If community do not spot signs of fire, then MKB is deemed necessary to be held at Friday night or Monday night. Nevertheless, if deemed urgent, MKB could be directly carried out without considering the time for its implementation.

Generally, MKB implementation is usually done in the dry season arrival. South Kalimantan is categorized as a region with numerous fire spots and susceptible for fire incidence at land spread in several peat land or forest.

Besides, several residents reported that $\mathrm{MKB}$ in their village is carried out as they face emergency situation due to conflict susceptive activities, such as election (either for presidential, local government head, or house of representative election). These situations are deemed to be susceptive friction and conflict activity amongst community residence due to their difference that can lead into riots. Riots for example usually are followed by burning, such as Banjarmasin riots in May 1998. In this situation, usually MKB is also carried out.

The community also stated that MKB is routinely held in month of Safar. It is believed as one of the 'hot' month and many dangers occur in this month, especially on the last Wednesday commonly called as arba musta'mir or rebo wekasan.

el Harakah Jurnal Budaya Islam Vol.18 No.2 Tahun 2016 


\section{Instruments}

Main instrument or object held or paraded in MKB is certainly Kitab Shahih Bukhari. As the unavailability of electricity in the past, parade participant also brought torch with them. Beside, some of them also bring a bottle of water. It would be subsequently sprinkled in certain parts of the house or around the house after the parade completed hoping that the house is dissociated from fire.

\section{Participants}

MKB participants are residents settling in certain area or village, especially male, either elderly, youth, teenager as well as children. Some requisite participants following the parade or group is not less than fourty people. They argue and lie on number of Jumat prayer pilgrims that are may not less than fourty people. Beside, MKB also indicates togetherness among the communities. Nevertheless, some also describe that MKB participant may less than fourty residents during the procession.

\section{The Procession}

There are several crucial stages carried out in $\mathrm{MKB}$. Before the commencement, $\mathrm{MKB}$ is preceded by discussion and agreement of community resident as they observed the signs, especially the incoming of dry season, fire occurrence in other region, or other causes. The agreement results are informed to the community.

On the appointed time, MKB implementation is preceded by praying Maghrib and Isya together in mosque as usual. Upon the completion of the prayers, MKB stages were commenced.

First stage of MKB involves salat sunnah Hajat together in mosque or langgar led by a religious figure. It is followed by reciting surah Yaasin and prayers. Subsequently, participants gather in front of the mosque or langgar and form a line or group to start walking around village while bringing Kitab Shahih Bukhari. Some other part of participant holding a bottle of water to be sprinkled surrounding house or environment. The parade is led by one or two people who later lead syair Burdah, salawat Kamilah, or prayers recitation. They walk around village street until they return to initial position, in the mosque or langgar. Upon returning to mosque or langgar, they recite again salawat Kamilah and offer tolak bala prayers and salvation prayers. The 
parade is completed with prayer recitation. MKB participants then go home by bringing the water which is subsequently sprinkled or watered around the house or nearby environment.

\section{Discussion}

Why do Banjar communities have to organize MKB to avert fire danger? This is certainly caused by many comprehended factors, such as religious thought and behavior that are still influenced by previous belief. According to Daud (1997: 8), Islamic teaching is not the sole reference for Banjar people religious behavior, as well as the ritual and ceremony. Thus, belief toward the unseen world could not be separated from Banjar community. Therefore, in context to comprehend fire cause, fire is not only caused by fire or human negligence, but also caused by unseen element, namely 'fire ghost'. As unseen entity, it is believed to be the cause of fire by Banjar community, commonly emerged in certain area and provided signs for its existence. Therefore, by observing the existing symptoms and in order to prevent fire, Banjar community usually organizes MKB tradition.

Comprehension toward ghost as unseen entity seemingly gives the idea that unseen power must be faced with unseen power. The result of every effort must be submitted to Allah as the owner of the knowledge concerning the unseen and the real one (QS. Al-Hasyar: 22). Therefore, begging for protection and help from Him (through salat Hajat) and wasilah merely toward something deemed to have unseen power becomes the best option.

It needs awareness to comprehend that all disaster and danger naturally come from Allah, therefore people have to be patient and return whatever happen merely toward Allah. These patience and tawakkal actually grown by ulama for community to face various life problem they suffer.

Fire itself in Banjar community traditional expression is categorized as disaster scrapping all hopes. According to them, "It is better for their house to be theft rather than to be burnt by fire". That means, they will still have hope if their house being theft as only one or two valuable properties missing, but fire will ruin their hope, as it burns all of their valuable properties as well. That is why, fire is considered as disaster that must be rejected, averted, or prevented. Not only by raising awareness, carefulness and preparing fire extinguisher instrument, but also by praying to Allah, in this matter by organizing MKB tradition.

el Harakah Jurnal Budaya Islam Vol.18 No.2 Tahun 2016 
MKB tradition is organized together and carried out in group of people or general community. It is understandable as fire disaster may strike lots of houses, and even the whole village. Several huge fire ever happened in Banjarmasin amongst them were fire in 1978 (Pekauman Urban Village), 1995 (Pekapuran Raya Urban Village), 1997 (Kelayan Tengah Urban Village), riots and fire of Banjarmasin City (May 1998), and others. Therefore, fire prevention must be carried out and become mutual concern. Therefore, MKN tradition is conducted by involving many people and carried by community of certain village in huge number of people.

MKB as tolak bala tradition is not merely aimed to prevent fire danger in its real meaning. This tradition implies basic values wanted by ulama. Islamic dakwah values are internalized through fixed culture and tradition. The values invite the community to perform worship, inviting community to do good and prevent damage, inviting community to care against their environment, raising mutual care, helping each other, and other numerous good values. MKB is also carried out to soften the heart, hold anger, so they would not do destruction, jeopardy, hostility, or riots and fight by burning, as frequent riots occur in several regions and followed by destruction or burning. More importantly, MKB is intended to be a medium for community to raise and develop excellent attitude, behavior and personality, passion, tawakkal, hard work, taubat, and returning entire problem merely to Allah swt.

MKB integrates many procession or religious activity is conducted together, starting from salat Hajat, Surah Yaasin recitation, Kitab Bukhari parade, reciting syair Burdah and salawat, and ended by prayers. Salat Hajat is intended as means to ask for Allah swt help for the village to be dissociated from entire danger and disaster, such as fire. It is only Allah that could protect them from any disaster.

Surah Yaasin recitation is believed as "the center of al-Quran" that could become wall protecting society from disaster, as incident experienced by prophet Muhammad saw when he was about to move from Mecca to Madinah. Allah had protected the prophet (Q.S. Yaasin: 9) from the chase of Quraisy people, He was protected one he stepped out from the house, during the journey and his hiding in Tsur Cave, and finally when he reached Madinah. That is why some ulama assume that reciting this surah is as a way to beg protection from Allah.

Banjar community believes that Kitab Bukhari is not merely a Hadis book that becomes their reference in studying religion. It is also believed to 
contain good luck or blessing that could prevent the village from fire. They rely this understanding on single history explaining that when Mongolian troops under Jengis Khan invaded Baghdad (as the Islamic civilization and knowledge center), the entire books were looted, burnt or thrown away to the river of Tigris, making its water turned into black, as its ink faded away. Community properties were looted, settlement were destroyed, burnt and fire existed everywhere for prolonged time. However, the miraculous thing happened as fire stopped. There was a single house not get burnt, as that house stored a set (four volumes) of Shahih Bukhari Hadis collection. For this incredible incident, ulama interpreted that such incident may occur as Allah permission and 'karamah' blessing of Imam Bukhari knowledge and advantage as Hadis book compiler, Shahih Bukhari. Therefore, MKB tradition is initiated by rendering Kitab Shahih Bukhari as "sacred" object and crucial part of this tradition.

Syair Burdah were written and composed by Muhammad ibn Sa'id alBushiri (1213-1295 M). Reviewed from literature aspect, Burdah is considered as something excellent due to its high level of literature value and its easily comprehended narration. There are many Badi' (literariness) element utilization created attractively. Words in Burdah are also beautifully selected and full of symbol and expression, describing how excellent literature capability and imagination of its composer as well. Besides, the meaning contained from each of its stanza or words are so deep. It reveals numerous religious teaching and historical moment. Accordingly by many literature experts, Burdah is considered as the second best compliment verses toward Prophet Muhammad SAW after Baanat Su'aad verses of Ka'ab ibn Zuhair (Adib, 2009: 31-32).

Despite many Banjar community not having knowledge concerning Burdah, they generally believe that Burdah has certain privileges that should be recited in certain religious tradition or activity. Meanwhile, Banjar community with pesantren educational background and broad knowledge on Burdah stated that Burdah advantages are not merely from literature side. From its writing and writer historical background, it shows various incidents accompanying its writing, and religious teaching values contained within, either concerning Prophet Muhammad SAW life history, compliment for him as well as life teaching (tasawuf) by its composer (Adib, 2009: 21, 82). In book written by Ibrahim al-Bajuri (deceased on $1861 \mathrm{M}$ ) titled: Hasyiyah al-Bajuri 'ala Matan al-Burdah, it is explained that syair Burdah contains property and privileges.

el Harakah Jurnal Budaya Islam Vol.18 No.2 Tahun 2016 
At least, Al-Bajuri explained twenty kinds of syair Burdah property based on its recommended principle (Adib, 2009: 82).

Syair Burdah could also be reviewed from its name. The orginal title of this composition verse is al-Kawakib ad-Duriyyah fi al-Madah ala Khair al-Bariyyah. However, Burdah name is more popular, easily remembered, and having historical value connected with Prophet Muhammad SAW. Prophet Muhammad SAW had ever endowed Burdah cloth he usually wore to Ka'ab ibn Zubair (deceased on $662 \mathrm{M}$ ), a famous poet who recently embraced Islam, as an honor for his composed verses containing honor and praise for Prophet Muhammad SAW and Islam. Such verses titled Baanat su'aad and were composed by Ka'ab as his regret and taubat for previously hostiling and insulting Prophet Muhammad SAW. Since then, Prophet Muhammad SAW' burdah fully owned by Ka'ab and became priceless memorable object in the future. Ka'ab then kept such Burdah cloth until the end of his life. According to history, burdah's cloth was subsequently purchased by Mu'awiyah ibn Abi Sofyan (first Khalifah and founder of Bani Umayyah) from Ka'ab heirs for 10.000 dirham and utilized as grandeur cloth each time statehood ceremony took place. Its intention might be raising charisma or authority of the Khalifah. This tradition continued and preserved by Bani Abbasiyah, commenced from Khalifah Ja'far al-Manshur that purchased the cloth for 40.000 Dirham and utilized as statehood grandeur apparel. Tradition of wearing Burdah cloth as statehood grandeur apparel is then continued hereditarily as well by Khalifah of Bani Abbasiyah until the final khalifah of this ancestry. A history explained, this Burdah shirt was destroyed (burnt) alongside with other Islamic khasanah by Mongolian army invasion against Baghdad (Adib, 2009: 23-24).

In Indonesia, syair Burdah has been well known since long ago, not only in pesantren, but also in wider community. Formerly, syair Burdah became Indonesian Moslem community tradition (including Banjar community). Every Friday night they recited syair Burdah with certain rhyme together. If it coincides with celebration, for example welcoming child birth, occupying new residence, facing the happening disaster, certain disease epidemic, and many others, syair Burdah is recited as wirid or hizib believed to be efficacious. There are several factors underlie the popularity of Burdah in Indonesia. (1) Burdah is in easy read verses with various verse song ('arudh), inviting unique attractiveness. Therefore, reciting Burdah could serve as entertainment to comfort souls; (2) Burdah contains salawat and history of prophet Muhammad saw. majesty. In Islamic teaching, reciting salawat is the most recommended 
and preferred sunnah worship. A huge bounty reward awaits for those who always recite salawat. As deemed to be part of salawat recitation, reciting Burdah believed as rewarding worship; (3) Syair Burdah full of tasawuf teaching, especially concerning position between faith and lust; (4) Syair Burdah is frequently used as wirid or hizib during celebration or religious activity and in certain critical conditions (Adib, 2009: 27-29).

Burdah's several advantages above lead to a belief that syair Burdah that is also called Qashidah asy-Syada'id contain mana, unseen power, or supernatural power to avert danger and also served as salvation prayer. Accordingly, it is frequently recited together by community as one of wirid for various activities including MKB. Henceforth, MKB is carried out together by Banjar community as means to reject fire. They also believes and conducts the following matter to avert fire danger:

First, to make the constructed house blessed and averted from fire, they built their house with odd number of pole. Woods utilized in constructing the house also the selected one; Banjar people usually avoid "kayu mata apian" woods, woods with holes resembling bird comrade. These woods deemed low quality woods.

Second, the community applied recitation called "Abi Darda Prayer" every Maghrib pray and sticking handwriting of Abu Darda Prayer behind the door or boundary hall of the house.

Third, they conduct salat Hajat, either individually at home, recite surah Yaasin, pray and sprinkle water of surah Yaasin around the house.

Fourth, Banjar community place wafak containing al-Quran verses or certain handwriting or symbol (Arabic alphabet) and placed in certain part of the house, for example behind the door, pole of the edge of the house, or house ceiling, as prerequisite in preventing fire.

Religious tradition that become community support in averting fire such as MKB is not a sudden emerging tradition, but through long process and dakwah acculturation of former ulama to provide awareness for society about Islamic teaching through tradition or culture. These implied the dakwah pattern and relationship between dakwah (Islam) and community tradition or culture. According to Kuntowijoyo (2001: 201), tradition is a description of mutual interaction and influences between religion and culture. First, culture influences culture in its formation; its value is religion. Second, cultures could influence religion symbol. Third, culture could substitute value and religion symbol system. Therefore, culture is expression of human creation, feeling and 
intention (in certain community) containing religiosity values and messages, having local philosophy and local wisdom.

According to Bagir (in Sahal \& Azis, 2016: 175), tradition is also utilized as aspect for considering and explaining religion and culture relationship or relationship between diversity and culture, so both could go in harmony. First, tradition considers religion respects culture as source of wisdom. In Islam, nationality, and ethnicity (that become cultural loci) could be positively considered as these sources of wisdom. Second, tradition considers culture as divinity wisdom heritage delivered through Prophet as God messenger along human history.

Such harmony between Islam and tradition, according to Khalil (2008: 14) is a reflection of compromized dakwah pattern or model application, specifically a call or invitation toward Islam by tradition or culture existed in community, either by changing culture format, purpose and intention, implementation procession, as well as inserting Islamic values to certain culture. Former ulama utilized these two dakwah models in different context. Undeniably alterable culture shall be acculturated and formatted with Islamic values. This dakwah model creates tolerable tradition or cultures to implement, as its uncontradicted nature and even containing Islamic value as well as becoming Islamic dakwah media. Therefore, culture utilized as one of media as well as cultural dakwah approach, specifically dakwah accommodating local culture and more unified with local community living environment (Umar, 2003: 3). In Banjar community, tradition such as baayun maulid, balamut, madihin mamanda, including $\mathrm{MKB}$, are tradition generated from compromised dakwah. Therefore, the inflexible culture is prohibited and abandoned through non compromised dakwah model.

It is such a custom if MKB as result of harmony between dakwah and culture contains many crucially elaborated values and meaning, either value and meaning in religiosity, social, or environmental context and other contexts. In religious context, $\mathrm{MKB}$ is one of Islamic dakwah media, as it invites community to do prayer together. $\mathrm{MKB}$ spiritually serves as crucial mean in providing awareness to community to get closer to Allah and contemplate that fire is not merely a disaster, but the most important thing would be returning entire problems to tawakkal merely to Allah swt. MKB is a sign that a village should actually has at least one religious figure understanding Kitab Shahih Bukhari to provide guidance and lesson to society. 
In social context, MKB is media for community resident to gather and escalating unity and integrity sense. It is a means of collaborating and share work between community resident in overcoming mutual problems. It is also means for doing good and reminding each other to avoid negligence concerning fire causes, raising awareness, and carefulness as well. In addition, it encourages community to perform discussion and function mosque or langgar as gathering location, beside certainly as means of worshipping; and it maintains togetherness in life for entire community resident.

In environmental context, $\mathrm{MKB}$ is a form of community local wisdom to mutually maintain environment from entire threatening aspects or danger, as fire may strick not only just one or two houses, but dozen of houses and even entire village. It raises collective responsibility sense toward environment;and mutual tolerance.

Local wisdom values contained within this tradition become substantial part and realization of dakwah implementation as explained by former ulama through interaction process involving cultural elements

\section{Conclusion}

Based on above explanation, it could be concluded that MKB is description of interaction or relationship harmony between Islam and culture in Banjar community. It contains several local wisdoms in religious context, social life, as well as environmental comprehension. These could be observed from MKB process that is lied based on religious behavior. By philosophy-religion means, MKB is human incapability acknowledgement in facing fire, so that they require support to return, complain, and plead. It is intentionally designed to fulfill or release anxiety and worries as well as provide them with hope, alienate them from hopelessness. There is still solution taken to prevent or avert fire as Allah swt. is the protector and the best possible rescuer.

Based on such reality, it would be completely right if experts conclude that Islam in Indonesia has been rapidly grown due to local cultural acculturation as well as creative and dynamic dialogue. In addition, it is grown through accommodative and compromise dialog, and integration that Islamic dakwah exists as rahmatan lil'alamin by noticing social and cultural environment through wisdom point of view. Dakwah is carried out peacefully, run effectively, and supported by local cultural resources.

el Harakah Jurnal Budaya Islam Vol.18 No.2 Tahun 2016 


\section{References}

Adib, Muhammad. 2009. Burdah: Antara Kasidah, Mistis, dan Sejarah. Yogyakarta: Pustaka Pesantren.

Ayatrohaedi, Ayat. 1986. Kepribadian Budaya Bangsa (Local Genius). Jakarta: Pustaka Jaya.

Daud, Alfani. 1997. Islam dan Masyarakat Banjar: Deskripsi dan Analisis Kebudayaan Banjar. Jakarta: PT. Raja Grafindo Persada.

Hapip, Abdul Djebar. 2008. Kamus Banjar Indonesia. Banjarmasin: CV. Rahmat Hafiz Al-Mubaraq.

Ideham, M. Suriansyah dkk (ed.). 2007. Urang Banjar dan Kebudayaannya. Banjarmasin: Badan Penelitian dan Pengembangan Daerah Propinsi Kalimantan Selatan.

Kahmad, Dadang. 2000. Metode Penelitian Agama. Bandung: Pustaka Setia.

Kartawinata, Ade Makmur (ed.). 2011. Kearifan Lokal di Tengah Modernisasi. Jakarta: Pusat Penelitian dan Pengembangan Kebudayaan Kementerian Pendidikan dan Pariwisata.

Khalil, Ahmad. 2008. Islam Jawa: Sufisme dalam Etika dan Tradisi Jawa. Malang:UIN Malang Press.

Kuntowijoyo. 2001. Muslim Tanpa Masjid: Esai-esai Agama, Budaya, dan Politik dalam Bingkai Strukturalisme Transendental. Bandung: Mizan.

Liliweri, Alo. 2007. Makna Budaya dalam Komunikasi Antarbudaya. Yogyakarta: LKiS.

Maman et al. 2006. Metodologi Penelitian Agama. Jakarta: PT. Raja Grafindo Persada.

Nasution, Harun. 1975. Falsafat Agama. Jakarta: Bulan Bintang.

Nuraeni, H.G., \& Alfan, Muhammad. 2012. Studi Budaya di Indonesia. Bandung: Pustaka Setia.

Pusat Bahasa. 2008. Kamus Bahasa Indonesia. Jakarta: Pusat Bahasa Departemen Pendidikan Nasional. 
Sahal, Akhmad \& Aziz, Munawir. (ed.). 2016. Islam Nusantara: Dari Suhul Fiqh hingga Paham Kebangsaan. Bandung: Mizan.

Sartini. 2004. Menggali Kearifan Lokal Nusantara : Sebuah Kajian Filsafat. Jurnal Filsafat, Fakultas Filsafat UGM, Jilid 37 Nomor 2:111-120.

Tim Penulis. 2000. Tradisi Tolak bala di Kalimantan Selatan. Banjarbaru: Bagian Proyek Pembinaan Permuseuman Kalimantan Selatan.

Umar, Husien. 2003. Dakwah Kultural Bagian dari Strategi Dakwah Islam, Tabloid Republika Dialog Jumat, edisi 27 Juni 2003.

el Harakah Jurnal Budaya Islam Vol.18 No.2 Tahun 2016 
el Harakah Jurnal Budaya Islam Vol.18 No.2 Tahun 2016 